GOODNOW, Trisha; KIMBLE, James J (eds.). The Ten Cent War - Comic Books, Propaganda and World War II. University Press of Mississippi, 20I7. ISBN 978I496810304.

DOI: 10.5I870/CEJISS.RI5030I

\title{
Trisha Goodnow, James J. Kimble (eds.): The Ten Cent War - Comic Books, Propaganda and World War II
}

Reviewed by Ing. Tomáš Kratina

The Ten Cent War - Comic Books, Propaganda and World War II (2016) by American authors and professors of Oregon State University and Seton Hall University Trischa Goodnow, James J. Kimble and co-authors. essentially deals with theses on the influence of American war propaganda from World War Il (I939 - I945) dosed through popular comics to the American population. By propaganda, the central theme of the book, we mean the purposeful dissemination of opinions, often rhetorically amplified to the extreme, whose goal is to persuade or directly change the opinions or critical considerations of groups of the population or the entire nation. The more the mass propaganda (for example, thanks to the media), the more aggressive and frequented, the more its persuasive effect grows, as the inhabitants themselves begin to believe it and themselves spread the ideas of propaganda among others. The issue of war propaganda is not a phenomenon of modern times at all, as the authors themselves state in their introduction, the germs have been known since ancient times. Over time, it has developed and become more efficient thanks to radio, magazines, television and today, thanks to the almost unlimited influence of the Internet and social networks. Throughout history, humanity has experienced that propaganda is often associated with ideologies and world- 
views that have the potential to influence the masses. Although propaganda is most often associated with the Nazi regime and the personalities of A. Hitler and J. Goebbels, very capable speakers in this area, as the peer-reviewed publication shows, the United States was not far behind in propaganda. After all, the image used on the cover of the book sufficiently expresses the power and message of propaganda and in which direction it is targeted. The used image from the comic depicts Uncle Sam in the background breaking a swastika (a symbol of Nazi Germany) and in the foreground the grotesquely fleeing Hitler and Mussolini in front of an angry (probably) American young man.

The book is thematically divided into I2 chapters, with a different author participating in each of them, which is one of the reasons why the book, or its components, is very diverse in terms of opinion and content. Each of the authors contributed to the topic of comic war literature with their own original insight. The chapters have the character of a written professional publication, structured into an introduction, starting points, conclusions, notes and cited literature. Declaratory statements are provided with reference to the consulted literature. Even for these reasons, the book can be considered a seriously prepared publication, which can serve as a quality basis for other subsequent professional publications.

To evaluate the reviewed book, and thus the topics and comics dealt with in the publication, we must approach it with at least basic prior knowledge of history and historical context. In particular, after the outbreak of World War II in Europe, the United States remained militarily out of the conflict (we do not consider the act of supplying Great Britain with military equipment and weapons as direct military intervention). The American public was strongly opposed to the US entering the war - it was not her war and was taking place on a distant continent in Europe. America changed its mind after the events at Pearl Harbor on 7 December 194I, and then war propaganda, armaments and other military activities began at full speed. In the introduction to the book, the authors note that various forms of propaganda, including pictorial comics, were a way to unite the nation and accentuate patriotic thinking on the way to war.

It would be illusory to consider contemporary American superheroes such as Captain America, Wonder Woman, Superman, Batman, The Sentinels and others who successfully flood world cinemas with fabulous profits, and who are known throughout much of the world to be the work of Hollywood today. In fact these superheroes appeared in comic books as early as World War Il, as the book describes. The authors of the book correctly identified and named the power of propaganda transformed into a fight between comic book heroes and designated enemies, Nazi Germany and Imperial Japan. This influence had 
an articularly strong effect on children and young people, because they wanted to identify with their hero and be like him. Whether a comic book hero fights the evil Nazis, the evil Japanese, the communists, the imperialists, the capitalists, the terrorists, the mad scientists or others is a mere variable that reflects the current national situation and foreign policy of the country.

Co-authors Katsion, Judy, Palmer, Wild and, marginally, others, notice the pernicious influence of (war) propaganda applied through comics to children and young people. Regarding the ideological impact of the comics, for which the authors cited child psychologists, who states that 'this kind of propaganda is more effective than any other kind'. Another man, who was ten years old during WWII said, 'In comic books Superman kill the Nazis, Batman kills the Nazis, so I also wanted to go and kill the Nazis'. Evidence of this is in the chapter Boys on the Battlefield: Kid Combatants as Propaganda in World War II and Boy Commandos Comic Book as Equipment for Living. It is quite clear that this group of young readers were captivated and influenced by colourful images, incredible adventures, the superhuman abilities of heroes or clearly defined attitudes. In addition, if comic book stories with a propaganda subtext are accentuated by the absence of a critical view of the world, living patterns, explanatory parental influence or a one-sided and limited perception, the intended impact is all the more effective. It is an indisputable fact that young people are especially easily subject to indoctrination by various ideologies or worldviews, and therefore propaganda has worked very successfully with them, here in a polarised form of the struggle of good against evil - superheroes against the Nazis, Japanese and other enemies.

The polarisation and contrasting behaviour of heroes / antiheroes, friends / enemies, the American political system / hostile political system and others is pointed out in the chapter Racial Stereotypes and War Propaganda in Captain America by D. C. Vance. An American hero or political system is always the right one, behaving predictably, honestly and fairly. He does not use deception and scorn to fight the enemy, but he always stands proudly in the face of the enemy. This chapter gives an example of Maxon, an opponent of Captain America, destroying his victims with poison from distance. Captain America, on the other hand, does not rely on sneaking, but on strength. We can say that American heroes, or the American nation in general, always have only positive qualities in propaganda war comics. They are brave, they act fairly, they have a sense of humour, they always play by the rules, they have a protective feeling and, if necessary, they do not hesitate to sacrifice for their nation. On the contrary, all enemies (Germans, Japanese) act cowardly and fraudulently, they are gloomy, do not play by the rules, see betrayal as another means of achieving their goals, fight from ambush and act only for their own benefit. Together with Vance, another of the authors, James 
J. Kimble, also notices a different cartoon depiction of American heroes and their enemies. Just as the good are always clean, well-groomed, muscular, modernly equipped, with a radiant smile, with women always devoted to them and with a perfect figure, the enemies are caricatured in monstrous or ridiculous forms. The Germans are often drawn with ominous grins and monocles with distinctive cheekbones dark-looking from under black uniforms. The Japanese, in turn, look like half-naked jungle savages with monkey features. Reality, pointed out by both authors, from the point of view of propaganda, is supposed to have clearly distinguished the warring parties into them and we.

Sawyer and Buescher focused on the sensitive area of law, torture and killing that appears in propaganda comics. The book cites Wonder Woman as an example. In the chapter Tell the Whole Truth: Feminist Exception in World War II Wonder Woman finds that the use of inhumane methods of warfare are advocated by two factors. First, in the case of Wonder Woman in particular, her methods of torture justify her being on the good side and therefore somehow more right. Second, the position of Wonder Woman is highlighted by her feminism, a single and strong woman, which distracts the reader from the real nature that torture or other inhuman treatment is humanly condemned and punished. However, if torture in comics is committed by the enemy, which is very often the case, it deserves the greatest contempt and bloody revenge. One of the group's similar topics is the question of the moral dilemma of justifying the killing that in war can be avoided. The search for an answer is again rationalised in several respects, as Judy and Palmer state in the chapter Kid Combatants as Propaganda in WWII - Era Comic Books, despite the fact that the enemies are cruel and spread fear and terror, they will never be able to kill the heroes in comics. Often the enemies are portrayed as stupid, incompetent, clumsy and surprised by the actions of the heroes. Moreover that war normalises violence. In these comics, violence is normal and common, even attractive. The elimination of enemies is often spiced with humorous quips from the heroes with a deliberate omission of the fact that they are also human beings. Scenes of death and dying, often brutal, are not expressed in a sinister or disturbing way in the comics of this kind; on the contrary, the heroes are still praised and decorated. And last but not least, there is the assurance that war is a responsible activity in which everyone must participate, without exception, and everyone can contribute to the defeat of the enemy through its merits. Similarly, in another chapter, Beyond the Storylines, Wilt authored Prize Comics magazine and What You Can Do to Win the War, improve in sports, learn to operate machines, etc.

Last but not least, the authors of the publication also marginally dealt with the ideas that currently (202I) resonate with society worldwide - genderism, feminism, racism / anti-racism. However, it is a question which is the subjec- 
tive consideration of each reader, whether the social views of the I940s can be assessed from the perspective of the modern age. However, it is an indisputable benefit, through a historical excursion, to get an idea of how the society of that time perceived these topics and how it dealt with them. It must be said that all the aspects described above appearing in American comics, appeared in exactly the same way in similar printed propaganda materials on the other side of the war. However, since the review concerned a book devoted to American propaganda comics, the reviewer did not explicitly address the other warring party, for example for comparative purposes.

\section{Conclusion and summary}

A peer-reviewed book by Goodnow, Kimble et al. (2016) The Ten Cent War Comic Books, Propaganda and World War II, deals with American comic books that were published during World War II. It focuses on a number of aspects of such magazines, but especially on their propaganda side, as one of the other ways to influence public opinion and gain support for the war. Due to the predominance of younger readers, the propagated national values and war effort were embodied in superheroes - Wonder Woman, Superman, Captain America, Uncle Sam, The Sentinels and others, who, as we know, did not disappear with the end of World War II. The authors critically reflected on the sensitive scenes of propaganda comics such as the normalisation of killing and torture, the normalisation of war, the ideological influence on youth, the dangerous polarisation of the world of them and us. The publication has the character of professional literature, as all conclusions, declaratory statements and information has its origins in the literature, which is duly referenced and cited. For this reason, the book can serve as a high-quality source of information in the preparation of university dissertations or other professional publications on the topic of war propaganda, the psychological effects of propaganda on youth and others. 